\title{
Stories of women at the top: narratives and counternarratives of women's (non-) representation in executive leadership
}

\author{
Heide Baumann ${ }^{1}$
}

\begin{abstract}
There is ongoing debate on a global level about (the lack of) women in senior leadership. Despite years of discussion about the alleged advantages of gender diversity progress has been glacial: top management roles and senior positions of power throughout society remain largely the preserve of men. This critical review explores how women's power is narratively constructed in two dominant European cultures, Germany and Britain, and how stories told about women's representation in top level executive leadership may impact individual identities, possibilities and ambitions. Using thematic and discourse analysis, this article covers empirical research, academic writing, government reports, non-fiction and fictional writing, and some anecdotal evidence gathered by the author, who has executive experience spanning two decades in multinational corporations. For reasons of space, I focus on just three of the stories currently dominating the discussion about gender equality in business: first, the story that there is nothing or little left to fight for, the battle is won; second, the story that gender equality is straightforward because there is a business case for parity; and third, the story that women are not at the top because women choose not to run the world. Each of these has a counternarrative supported by empirical and anecdotal evidence, which I outline; nonetheless, I argue, they serve to maintain the status quo in leadership, reassuring those in power that they have no responsibility for (and therefore no responsibility seriously to address) the lack of women in top positions. I suggest on the basis of the evidence that the cultural narratives of Britain and Germany are remarkably similar and that the prospects of gender equality at the top occurring in our lifetime are dismal. A juxtaposition of the (contradictory) narratives paints a more holistic picture of the discursive sea we all swim in, relevant to scholars of gender equality and women's leadership across disciplines as well as government policy departments. As qualitative methodologies, narrative and discourse analysis cannot provide definitive answers. They can, however, provide a basis for reflecting on how dominant stories impact individuals and the cultural atmosphere. This article is published as part as part of a collection on the role of women in management and business.
\end{abstract}

\footnotetext{
${ }^{1}$ Cambridge University, Cambridge, UK Correspondence: (e-mail: hab55@cam.ac.uk)
} 


\section{Narratives and knowing}

Stories are how we organise our lives, how we streamline our desires, and sometimes they fall short, and sometimes they disappoint us, and they always matter. (Penny, 2014: 214)

ost-structural philosophers such as Michel Foucault (1970); Deleuze and Guattari (1980) have highlighted the importance of narrative as a basic structure for human knowing and action, as a means of constructing one's sense of self. ${ }^{1}$ Psychologist Jerome Bruner (2004: 4) calls self-making a narrative art, claiming that there is "no intuitively obvious and essential self to know, one that just sits there, ready to be portrayed in words. Rather, we constantly construct and reconstruct our selves". The stories we tell to ourselves and of ourselves can "enhance the sense of self [...]-or even alter one's sense of identity" (Richardson and Adams St. Pierre, 2005: 965). Judith Butler (2005: 7-8) suggests that "when the 'I' seeks to give an account of itself, it can start with itself, but it will find that this self is already implicated in a social temporality that exceeds its own capacities for narration [...]. The 'I' has no story of its own that is not also the story of a relation-or set of relations-to a set of norms".

The following examines three powerful narratives that are in play in mainstream news media, fictional writing, non-fiction and self-help books, as well as in some academic writing, about women and leadership at the highest level.

\section{1. "We have come a long way; the battle is won"}

When historians look back on the first 15 years of the $21^{\text {st }}$ century, they may well conclude that the period witnessed the first stage of a fundamental rearrangement of civil society, exemplified by a substantial influx of women into leadership positions. (Thomson and Laurent, 2015: xiv)

Narratives of success. "We've come so far. We really have" claimed UK Government Minister Priti Patel, speaking at an industry conference to mark international women's day (see also WICT, 2016). She reminded her audience that less than a hundred years ago women were fighting for the right to vote. Her emphasis on celebrating the achievements of the suffragette and women's liberation movements and her optimism about steady progress is not uncommon: Emily Wilding Davison's death in 1913, when she threw herself in front of King George V's horse for the cause of women's suffrage, has been a favourite anecdote at women's conferences in 2016, told to inspire cheerfulness about the tremendous progress made since. Catherine Hakim (2012: introduction), formerly senior research fellow at London School of Economics, claims that the legislative milestones which enshrined equality in the UK law have successfully stimulated "massive changes" and transformed women's lives (the Equal Pay Act took effect in 1970, and the Sex Discrimination Act was passed in 1975). The German journalist Bascha Mika asserts that women have "not only come a long way but circumnavigated the world several times over"2 (Mika, 2012: 47), contrasting circumstances in 1900 with equality legislation now in place. To prove how far we have come, Alison Wolf, Professor of Public Sector Management, reaches all the way back to Jane Austen's decision in 1802 to break off her engagement: "to marry or not was a once and for all decision. Everything else about her life would follow from it; and her control over her own fate was, either way, deeply limited. No educated female in the developed world today stands where she stood. And that is progress" (Wolf, 2013: 286).
According to Tutchell and Edmonds (2015: 3) the British "national consensus" is that gender parity is only a matter of time: "just wait a little longer and all will be well". That reflects a widely held belief in both Germany and Britain that the struggle for gender equality is effectively over: "we're already there [...]. Women are allowed to vote? Tick! They are allowed to study? Tick! They can earn their own money? Tick! Women can achieve the highest political office and become chancellor? Tick!"3 (Wizorek, 2014: 11). Sir Stuart Rose, former Chairman of Marks \& Spencer and a life peer, has his own list of proof points and insists that "there really are no glass ceilings despite the fact that some of you moan about it all the time [...]. You've got a woman fighter pilot who went on to join the Red Arrows [...]. I mean what else do you want, for God's sake? Women astronauts. Women miners. Women dentists. Women doctors. Women managing directors. What is it you haven't got?" (Banyard, 2011: 1). In Germany the sentiment is similar: according to a study conducted in 2013 by the Institut für Demoskopie Allensbach ${ }^{4}$, two thirds of German men believe that women do not need more equality, and $28 \%$ believe that too much emphasis is being placed on equality (Domscheit-Berg, 2015: 13). Doris Lessing, a Nobel prizewinner for literature, worries for the men that we have arrived at "an unconscious bias in our society: girls are wonderful; boys are terrible" (Banyard, 2011: 1). Rosin (2012: 5) has even declared the "end of men", and asserts that "our vast and struggling middle class, where the disparities between men and women are greatest, is slowly turning into a matriarchy, with men increasingly absent from the workforce and from home, and women making all the decisions". Wolf (2013: 2) explains how "working women are creating a new society" and claims that "incrementally, but irreversibly, women's penetration in the world's elites is changing both men and women's daily activities and their personal lives".

Professor in Human Resource Management Durbin (2016: 14) has concluded that feminism has become a "dirty word" or at best a controversial term. For some young women, rejecting it has become a way to construct themselves as modern and liberated (Durbin, 2016: 13, Kelan, 2012: 57). Post-feminism seems de rigueur: more than 40,000 facebook users have "liked" the "women against feminism" page since 2013. They might agree with Emily Hill, in her recent Spectator feature: "Feminism is over, the battle is won. Time to move on". For the young writer, feminists are "determined to drain the fun from life, and illustrate how awful it is to be a woman" (Hill, 2015). In Germany, too, a popularly held view especially among young women (Echtermaier, 2014) is that feminism is past its sell-by date, and patriarchy from yesteryear (Dössel, 2010). The author and journalist Von Rönne (2015) declared, aged 24, that feminism disgusts her. Her April 2015 article in the broadsheet Die Welt made her a media phenomenon overnight (Haas, 2016).

\section{Statistics: another side to the story}

Women hold only a small proportion of the most powerfuland best paid-jobs in Britain. The odds against this situation occurring by accident are astronomical. (Tutchell and Edmonds (2015: 176).

The statistics of our 'supposedly 'equal society', with nothing left for women to want or fight for" (Bates, 2014: 14) tell a different story. Official data and research published by the government, leading think tanks and consulting firms shows that we have not come as far as popular discourses suggest. At a time where women hold the majority of academic qualifications and make up half of the workforce, the hard data indicate that men still have a firm grip on all positions of high impact decision-making, opinion 
leadership and power in the United Kingdom and Germany (Tutchell and Edmonds, 2015: 7, 26; Domscheit-Berg, 2015: 16-20). The average gender pay gap in the United Kingdom and Germany is among the worst in Europe; over the past decade both countries have dropped in equal pay rank (World Economic Forum, 2015). In some (male)-dominated industries and at the top of their profession, men are getting paid more than twice as much as women, for the same work (Anonymous, 2015; TUC, 2015; Allan, 2016). Sex discrimination at work occurs for an overwhelming majority of mothers in the United Kingdom (Wizorek, 2014: 109; HM Government, 2016). More than half the female UK and German population have reported sexual harassment (YouGov, 2016). Everyday sexism and social and online media abuse against women have become well-documented, large-scale phenomena in both countries. The much touted equality legislation appears to have failed to produce the intended outcomes-the real situation remains unequal (Drescher and Schrott, 2015).

In Europe, including the United Kingdom and Germany, women now represent $60 \%$ of the workforce (Rosin, 2012). Twenty-first-century women are more academically qualified then men, making up 55\% of graduates in Germany (Lorenzo et al., 2016) and $60 \%$ of talent in Europe (European Commission, 2012), as well as globally (Wittenberg-Cox, 2012). However, in the United Kingdom and in Germany, men hold an overwhelming majority of the most senior positions of power throughout government, private companies, the media, the judiciary, law enforcement and the military. In the United Kingdom, as of March 2016, men represented 100\% of Generals, Major Generals and Brigadiers; 94\% of CEOs in Britain's 100 biggest companies (FTSE 100); 95\% of Chief Editors of national newspapers (that is, one woman); $92 \%$ of Supreme Court Judges; $86 \%$ of Police Chief Constables; $79 \%$ of university Vice Chancellors and 71\% of MPs (see Tutchell and Edmonds, 2015: 7,26 ). In Germany, the picture is similar, with men representing $100 \%$ of Generals and Admirals; $100 \%$ of CEOs in Germany's 30 largest listed companies (DAX); 93\% of top managers; $98 \%$ of Chief Editors for the German media; $89 \%$ of senior (C-4) professorships; $69 \%$ of federal constitutional judges; $64 \%$ of MPs.

When it comes to top positions, then, women are either completely absent, participate in homeopathic doses, or at best form a weak minority (Domscheit-Berg, 2015: 16-20). The fact that both countries now have a woman political leader seems unlikely to change these statistics, if the case of Angela Merkel over the past decade is anything to go by: between 1994-2014 the proportion of women in leadership positions in Germany grew by only $0.7 \%$ (Lorenzo et al., 2016: 4).

When it comes to equal pay, quantitative data suggest that at current pace our granddaughters will still be waiting for parity. The latest World Economic Forum gender gap report (November 2015) calculates that it will take another 118 years-or until 2133 - until the global pay gap between men and women is closed. Since the annual study, which compares 145 countries for overall gender equality, was first published in 2006, both Germany and the United Kingdom have dropped in overall rank (Germany to 11th place from 5th in 2006, the United Kingdom to 18th from 9 th in 2006). The relatively slow pace of progress in comparison with other countries is echoed in the report's assessment that Germany is 60 years away from closing its pay gap. Professional services firm Deloitte forecasts that pay parity is another 53 years away in the United Kingdom (Codd and Lewis, 2016). Against a 16\% European average, Austria (23\%) and Estonia (29\%) are the only countries with a greater gender pay differential than Germany's (22\%) (World Economic Forum, 2015). The UK fares marginally better at 20\% (Eurostat, 2016: 51), yet a TUC analysis shows that in the United Kingdom, the highest paid men take home 55\% more than their female colleagues (2015). The German news magazine Focus has warned of a huge pay gap particularly in the legal profession, which has a $39 \%$ pay gap, and in senior management, with a difference of $37 \%$ ("Riesige Gehaltslücke: Diese Jobs sollten Frauen lieber nicht ergreifen"; Anonymous, 20.03.2015); but the warning the piece gives women to avoid those professions seems to appeal to them to collude with the status quo. Despite the UK Equal Pay Act, women's lifetime earnings lag on average between $£ 300,000$ and $£ 423,000$ behind men's (CMI, 2013; Allan, 2016).

This data shows a clear discrepancy between what national and European law on equal pay appears to guarantee and what is being delivered, as well an adverse trend in both countries considered here.

In the United Kingdom, $60 \%$ of women have had a male colleague behave "inappropriately" towards them (Slater and Gordon, 2013), 64\% of all women and $85 \%$ of young women between 18-24 have received unwanted sexual attention in a public place (YouGov, 2016), and 33\% of girls aged 13-17 have experienced some form of sexual abuse (Barter et al., 2009). A recent government study (HM Government, 2016) found that $77 \%$ of women had a negative or possibly discriminatory experience during pregnancy, maternity leave, and/or on return from maternity leave. Such discrimination has risen from $45 \%$ in 2005, according to the report. In Germany, according to the Federal Department for family, elderly, women and youth (note, adult men are not deemed to need a dedicated Government Department), $58.2 \%$ of women have experienced sexual harassment either at work or in society at large (Wizorek, 2014: 109).

A new generation of feminists is speaking out. Anke Domscheit-Berg, for example, former Microsoft executive, internet activist and politician has published her "wake-up call", titled "A little bit equal isn't enough! Why we are still a long way from gender equality" 5 . A public debate on everyday sexism has been instigated in the United Kingdom and Germany. The 2013 hashtag "outcry" 6 , which coincided with the Stern journalist's, Laura Himmerreich's, report on sexist behaviour by the chair of the German liberals Rainer Brüderle (FDP), created a "media hurricane" (Bielby and Matthes, 2015: 253). Initiated by blogger Anne Wizorek, it was the first ever hashtag to win the coveted Grimme Online Award (the Grimme-Preis is the most prestigious award for German television) and led to Wizorek's manifesto for a contemporary feminism (Weil ein \#Aufschrei nicht reicht. Für einen Feminismus von heute, Wizorek, 2014). Sexual attacks on a large number of women during the new year celebrations of 201516 in Cologne reignited the debate over how vehemently and how often a woman needs to say "no" to sexual advances before the law is on her side (Emcke, 2016). In the United Kingdom, Bates' (2014) "everyday sexism" blog, started in 2012, has drawn media attention and resulted in a book summarizing key themes from more than 100,000 entries to the blog. Kat Banyard argues that we are faced with The Equality Illusion (2011), and that feminism continues to be one of the most urgent and relevant social justice campaigns today, while Kira Cochrane celebrates the rise of fourth wave of feminism in all the rebel women (2013). "Many recent stories have shown that any woman who is visible in our society-whatever her age, her sexuality, her ethnic background, her politics-is vulnerable to threats of rape and violence" writes Natasha Walter in the introduction to the 2015 edition of her 2010 book Living Dolls: The Return of Sexism (Walter, 2015: xvii). That is corroborated by numerous female journalists, MPs, bloggers and twitter users who have experienced severe online abuse on gender grounds, whether they were making "feminist" observations or not (Penny, 2014; Wizorek, 2014; Criado-Perez, 2015: 121-127). A cross party national campaign was launched in May 2016 to tackle growing online misogyny in the United Kingdom, following research which revealed that during a 3-week 
period from the end of April 2016, 6,500 individuals received 10,000 aggressive tweets containing the words "slut" or "whore". But German federal president Joachim Gauck has dismissed the debate in the FRG as "moral fervour", and concluded that "whilst there's still ground to be covered on the female question I can't detect a grave, widespread adverse male attitude towards women in this country"7 (Mascolo and von Hammstein, 2013).

Narrativising the battle as non-existent. Presented with the statistics, "many men try to insist each example of unfairness is either unusual or temporary or trivial. And many women are loath to draw any general conclusions and are inclined to say that life is too short to make a fuss every time a woman is treated worse" (Tutchell and Edmonds, 2015: 52). Fiske and Lee (2008) have identified a type of sexism that questions the notion that sexism still exists, and disapproves of those who think it does. The narrative thus constructed is that no structural action is needed because women can achieve parity on an individual basis. Individual businesswomen I have spoken with have even expressed doubt that the "terrible" statistics I cite are true, as such things "don't happen in my world".

Some academics have warned that the "we've come a long way" narrative leads us to take our eye off the ball: "where there has been no powerful movement campaigning for women's rights, women have suffered reverses, progress is not steady and inexorable, without a powerful movement maintaining the pressure, improvements come very slowly, tend to be fragile and the position of women is likely to be eroded" (Tutchell and Edmonds, 2015: 4). This seems to be supported by recent examples: the pace of change has not kept up after the UK Davies closing report in October 2015, and numbers of women on Boards have slightly declined over the nine subsequent months (Vinnicombe et al., 2016). In Germany, Drescher and Schrott (2015: 1) have noted that changes are slow and variable, with female Board representation declining year on year despite media coverage on gender parity. A leading academic in the field of gender in educational leadership, Coleman, (2011: 12) believes that the prospects of achieving progress without the aid of further policies are grim: "It seems not only inequitable but positively bizarre that only around $11 \%$ of the directors of boards of the top FTSE companies in the UK are women and that without legislation to change that situation, as in Norway, there is little to indicate a major change in the near future". Other academics have criticised the current approach for its slow pace and failure to deal with the deep-rootedness of gender inequality as well as the incremental nature of reforms over a lengthy timeframe (Gatrell and Swan, 2008). McTavish and Miller (2006: 5) have argued that "there exists a male-dominated leadership echelon and masculine organisation culture in UK and European organisations, which knowing that undervaluing female employees is illegal, continued to do so for more than 30 years". It is claimed in this context that policymakers and governing bodies may have a vested interest in maintaining the status quo because they are men (Thomson and Laurent, 2015: 8; Durbin, 2016: 1517). Sattelberger (2011: 429), formerly Board Member of one of Germany's largest companies, Telekom, has observed "big words for big projects, in the foreground a bowing to a big conviction, awards collected for activities without corresponding results, in the background silent ignoring, forgetfulness, unconscious denial, subtle sabotage, or acceptance of a lack of change" 8 .

\section{2. "There is a compelling business case for gender parity"}

The existence of a business case is increasingly recognised. (European Commission, 2012: 2)
A key case put forward in favour of gender parity by those who acknowledge that we are not there yet is that having more women in leadership positions is advantageous both for individual companies and for the economy at large. The key tenets of the business case narrative are:

- Tapping into women's economic potential would add a 'third billion' of individuals to the workforce, contributing to the global economy and stimulating growth.

- In times of an ageing population and skills shortages we can no longer afford to miss out on half the talent.

- More women in management positions provide a better mirror of the consumer market where women control the majority of spending decisions.

- More women on Boards makes for better governance, ethics, decision-making, creativity and innovation.

- More women at top levels of an organisation leads to better organisational and financial results.

- More women in top positions will pave the way for even greater numbers of women.

The "business case" narratives. The potential impact of women-as the "third billion"-on the global economy has been projected to be at least as significant as that of China's and India's respective 1billion-plus populations (Aguirre and Sabbagh, 2010). Consultants McKinsey (Woetzel et al., 2015) assess that US $\$ 12$ trillion could be added to global GDP by 2025 by advancing women's equality. In early 2016, consulting firm Boston Consulting Group calculated that $€ 200$ billion of additional value could be added to the German economy alone from tapping into the "dormant potential of women" (Lorenzo et al., 2016). In 2013 the Women's Business Council, which advises the UK Government, concluded that "by equalising the labour force participation rates of men and women, the United Kingdom could further increase GDP per capita growth by 0.5 percentage points per year, with potential gains of $10 \%$ of GDP by 2030 ". Supporters of the talent pool logic argue that women are an underutilised resource and that making better use of the aforementioned $60 \%$ of academically qualified women will yield significant business benefits. "Warren Buffet, that successful and celebrated investor, famously said that he has done so well because, in a male-dominated world, he only has to compete against half of the population" (Tutchell and Edmonds, 2015: 177).

Women, it is claimed, control $70-85 \%$ of all consumer purchasing, through a combination of buying power and influence (Brennan, 2015). According to the Harvard Business Review "women now drive the world economy"(Silverstein and Sayre, 2009); more women in management positions, therefore, would provide a broader insight into economic behaviour and consumer choices, and might boost sales from products and services that are more in line with consumers' needs and preferences. In this context, academics Singh et al. (2006: 133) note that "understanding the female customer, purchaser, stakeholder, client and employee perspective may be difficult for an all-male board."

The McKinsey Women Matter (Desvaux et al., 2007, 2010) studies have made the case that companies with three or more women in senior management functions score higher than companies with no women at the top on nine criteria including leadership and direction. Other studies have linked female diversity to creativity and innovation, for example a study of 1,000 international teams conducted by London Business School (Gratton et al., 2007). There is a view that women bring a different and complementary range of experience, opinions and angles, leading to a wider range of thinking processes and 
decisions based on evaluating more alternatives compared to a more homogenous group of men. Several studies have shown that the quality of corporate governance and ethical behaviour is high in companies with a high share of women on Boards (Adams and Ferreira, 2009, Abbott et al., 2012) with researchers theorising "that the female board member contributes to better independence of the board, improved monitoring, and reduced 'group think' " (Catalyst, 2013: 8). An empirical study examining more than 900,000 private limited UK companies found that companies with female directors had a lower risk of insolvency (Wilson and Altanlar, 2009) and "some ask whether the financial crisis would have been as bad had Lehman Brothers been Lehman Sisters, given research suggesting a link between testosterone levels and risk-taking" (Schumpeter, 2015). This comment references research by the Cambridge University neuroscientist Coates (2012), who found that when it comes to making and losing money women may be less hormonally reactive then men.

Improved financial performance is regarded "by some people in the commercial world as the most important part [of the business case] [...] and great efforts have been made to demonstrate that it is true." (Tutchell and Edmonds, 2015: 180 ). Since 2004, a series of studies by consulting and research firms as well as academics have claimed that companies with the most women board directors show better financial performance (Catalyst, 2004; Joy et al., 2007; Kotiranta et al. 2007; Desvaux et al. 2007 and 2010; Terjesen and Singh, 2008; Deszo and Ross, 2008; Adler, 2009; Herring, 2009,Carter and Wagner, 2011, Credit Suisse, 2012). For example, Desvaux et al. (2007) showed that companies with the most gender-diverse management teams had 1.7 times higher stock price growth and their average operating profit was almost double compared to the industry average; in 2010 they reported a $41 \%$ higher return on equity for companies with the highest share of women directors compared to companies with no women on their boards. Catalyst (2007) found that companies with most women directors outperformed those with the least in terms of return on equity (53\% higher) return on sales (42\% higher) and return on invested capital $(66 \%$ higher), in 2011 they assessed the latter as $26 \%$ higher.

And women, it is argued, will pave the way for more women: the claim is that women in leadership positions will ensure a greater influx of additional women once "critical mass" is achieved (Joecks et al., 2013). "Women will tear down the external barriers [to women's advancement] once we achieve leadership roles. We will march into our bosses' offices and demand what we need [...]. Or better yet, we'll become bosses and make sure all women have what they need" (Sheryl Sandberg, cited in Slaughter, 2015: 16).

Counternarratives. No great shifts have been noted at the very top of organisations since the economic argument was first made around a decade ago. In Germany, the Boston Consultancy Group has observed (Lorenzo et al., 2016: 4) that "despite years of debate about the advantages of gender diversity in corporations, management positions are still mainly the preserve of men" (Lorenzo et al., 2016: 5). The trajectory can even be downward: Coleman (2011: 3) notes that the 2009 edition of the Sex and Power index published by the Equality and Human Rights Commission (EHRC) recorded fewer women in six categories than there had been over the 5 years previously.

Like any other commercial business case, the gender parity case relies on the validity of its assumption set. It hinges on narratives about differences in the leadership styles of men and women, where "feminine" styles are deemed more likely to engender success and more suited to modern businesses. A range of academic research suggests that this is not the case. In her study of 917 managers in Norway, the sociologist Solberg (2013) concluded that men's and women's leadership styles differ only marginally: nearly as many male managers show a "feminine" leadership style as there are female managers with a "masculine" leadership style. A 2015 article in The Economist concluded: "those arguing that women leaders are different, and better, may have the best of intentions. But they are piling flimsy evidence on dubious argument to produce politically correct hokum. In some societies such claims risk reinforcing stereotypes about the sort of job that women are 'good for'" (Schumpeter, 2015).

Academic evidence appears to not underpin the claims made by Catalyst, McKinsey, the Davies report and numerous journalists, that more women lead to better financial results: academics Van Dijk et al. (2012) completed a meta-analysis that showed that the link between diversity and positive performance may be based on rater biases. Professor of psychology and management Alice Eagly, citing two meta-analyses, one of 140 studies on Board gender diversity (Post and Byron, 2015) and one of 20 studies (Pletzer et al., 2015) concludes that “despite advocates' insistence that women on boards enhance corporate performance and that diversity of task groups enhances their performance, research findings are mixed, and repeated meta-analyses have yielded average correlational findings that are null or extremely small" (Eagly, 2016: 119).

Sociologist Kreissl (2000: 10) wonders whether indeed the few successful women in classical male professions are so successful because in reality they are the "better men" and have internalised the value system of competition, assertiveness and egotism to perfection. Academic Maier (1999: 89) has similar observations, namely women in dominant positions tend to internalize a requirement for "becoming like men". It is "difficult for women to fit in without making themselves into clones of the men they see around them" (Tutchell and Edmonds 2015: 9). Sociology Professor Wajcman (1998: 7-8) has described masculine behaviour as a necessary success criterion: "Women's presence in the world of men is conditional on them being willing to modify their behaviour to become more like men or to be perceived as more male than men". Gini (2001) goes further to claim that women feel they have to beat men at their own game by demonstrating they can be tougher and more resilient. At a recent panel on "female quotas or other routes to Board diversity" (March 2016) I heard a woman in a Non-Executive Board role report with pride that male Board members compliment her on being likeable because she is "not really a woman", and another woman describing men who affirm "we are okay with you, other females start to cry, are incompetent and in any case we can't find any".

"Trickle-down" feminism, too, has its counternarrative. Back in 1949, De Beauvoir (1979: 21) pointed out that women are neither a minority group nor a homogenous unit with a common history, culture, religion or social class, and according to academics (Mattis, 1993; Rindfleish, 2000; Mavin, 2006), sisterhood and solidarity behaviour sets expectations that senior women do not want to or cannot fulfil, and they often dislike being singled out on the basis of their gender. An example is Julia Jäkel, CEO of the German publishing house Gruner+Jahr:

Just because I am a woman, do I stand for women's issues? Wake up, folks: I studied history and politics, and my hobby horse was international affairs. Are you nuts? I worked for the Financial Times Germany, was responsible for magazine titles like Beef and National Geographic-all boys' titles. I've only been pushed into the girls' corner since I started sitting on the Board ${ }^{9}$. (Häming and Tietz, 2012).

Foster (2016: 79) attacks the trickle-down narrative as demeaning, unfair and narrow-sighted: "The idea that women 
in power act for other women is not only insulting-men are rarely assumed to do so [...]-but also neatly overlooks competing interests". For example, Margaret Thatcher promoted few women and her son described her as "the toughest man on the government" (Tutchell and Edmonds, 2015: 229). She was "harming thousands of women's lives and communities because her class interests mattered for more to her than any modicum of gender solidarity" (Foster, 2016: 79). These kinds of counternarratives suggest that the few women who have made it into top positions are "tokens", yet they are viewed as representative of the entire female community (Kanter, 1977).

\section{Lean in ${ }^{10}$ and brush the glass ceiling shards out of your hair ${ }^{11}$ : it is women's choice to not run the world}

Why don't women run the world? Maybe it's because they don't want to. Lisa Belkin (2003)

In Britain and Germany and further afield a much touted reason for female underrepresentation in leadership is women's own choices. The key narratives are that women lack the ambition and appetite for power; women are holding themselves back and need to grow in confidence; and success is down to individual effort (any woman willing to work hard can make it to the top).

Narratives of lack. Women's lack of desire for power and its associated benefits is allegedly the reason why they are overtaken by men in their careers after outperforming boys at school and being awarded more university degrees (Tutchell and Edmonds, 2015: 176). Hakim claims that $50 \%$ of UK women accept the sexual division of labour and treat work as a secondary activity to fit around their domestic arrangements (1996), and that men and women often have different life-goals: "Despite feminist claims, the truth is that most men and women have different career aspirations and priorities" (2011: summary). She has argued that men are far more "careerist" than women (2011: 22) and in her "preference theory" she contends that only $20 \%$ of women will prioritize work, instead choosing to be "home-centred" (Hakim, 2004: 14-15). In August 2016, Kevin Roberts, then chairman of UK advertising network Saatchi \& Saatchi ${ }^{12}$ claimed that women's ambition "is not a vertical ambition, it's this intrinsic, circular ambition to be happy." (O’Reilly, 2016). A $2003 \mathrm{New}$ York Times Magazine article, "The opt out revolution", lays the blame on women's rejection of the workplace as they are "increasingly deciding that they don't want to do what it takes to get there" (Belkin, 2003). The decreasing proportion of women as seniority rank rises has been described as the 'leaky pipe' syndrome. Peninah Thomson, who runs a cross-mentoring programme for FTSE-listed companies, speculates that it is down to women opting out because of "the risks they perceive in seeking high office, perhaps, or the pressure, the work load, the impoverishment of their family life that they fear would accompany promotion to high office" (Thomson and Laurent, 2015: 148).

In Germany, women have been described as cowards who withdraw into the comfort of coupled life and motherhood (Bierach, 2002; Mika, 2012) and fail to enjoy the competitive pressure of a job (Mika 2012: 12-13). They are accused of being dim-witted, lazy and dishonest: "dim-witted because they don't grab what's rightfully theirs. Lazy because they find the continued wrestle for projects, budgets and resources too exhausting come their mid-30 s at the latest, and too political. Dishonest, because they won't admit that they voluntarily withdraw into private life and blame the glass ceiling for this decision." ${ }^{33}$ (Bierach and Thorborg, 2006: 21). In this view it is not men's fault: women in Germany are accused of suffering from Stockholm syndrome
(Mika 2012: 19,26) rather than pulling their weight to address the lack of parity in positions of power. The status quo is portrayed as the conscious and voluntary choice of a 52\% strong female majority (Bierach and Thorborg, 2006: 22; Mika, 2012: 18-19).

In addition to a lack of career ambition, the most often-cited barriers to women's progress into senior leadership are lack of self-belief and confidence (ILM, 2011; Credit Suisse, 2012; CMI, 2013; Durbin, 2016; Owen, 2015). Numerous courses have been launched to help women assert themselves and gain "a seat at the table" (Fidelio Partners, 2016), such as (for example) the Cambridge Judge Business School's Rising Women Leaders Programme. Professor Sucheta Nadkarni, who leads the initiative, explains what "female millennials with ambition" can do "on an individual level to practically and positively increase their chances of securing a top job", "setting aside the doom and gloom figures". (Judge Business School, January 2017). Professor of Sociology of Organisations Alicia E. Kaufman claims that while much has been said about stereotypes and the traditional roles of women, the real crux of the matter is that women are blocking their own access to upper management. She claims that they "participate as much as or more than men in their own 'devaluation'". Kaufman cites "innocuous patterns" that limit women's capacity for thought, action and decision-making and "self-imposed demands" leading women to a level of exhaustion that "sometimes ends in anxiety attacks" (2008: 10, 30, 139).

"Lack" narratives say that women need to try harder. Men have made the rules (Looman, 2011) and "maleness" is inherent to management (Schein, 2007; McInerney-Lacombe et al, 2008; Terjesen et al., 2008). Women must and can do their best to fit in: a plethora of guidebooks and "cheery instruction manual(s) for how to navigate modern patriarchy" (Penny, 2014: 1) suggest that a woman's way to the top is through individual effort and smart play (Frankel, 2005; Knaths, 2009; Schneider, 2011; Edelburg 2012; Och and Daniels 2013). In the United Kingdom, facebook COO Sheryl Sandberg has sold more than 2 million copies of Lean In. Women and the Will to Lead (2012), a book which claims that any woman willing to work hard can climb the corporate ladder all the way to the top: it is simply about not taking her "foot off the gas". Sandberg's central argument is that it is women's behaviour that causes gender inequality, rather than patriarchal power structures in work and society. This is an old premise: when Betty Friedan, in 1963, described "the problem that has no name" of housewives asking themselves "is this all?", a New York Times reviewer responded "The fault, dear Mrs Friedan, is not in the culture but in ourselves" (Rhode and Kellerman, 2007: 4). "There are supposed to be no structural problems, just individual maladaptation", comments Penny (2014: 7), and women are advised to concentrate on benefits arising from networking, mentoring and following the career advice of female role models (Coleman, 2011; Durbin, 2016). When asked to comment on the secrets of their success, reports Coleman, successful women tend to claim that anyone with "dogged determination, confidence and clarity" as well as "enthusiasm, passion and commitment" and who works harder than any man can make it to the top (Coleman, 2011: 47, 50). The tenor of these contributions is that women are just not trying hard enough and leave the football pitch, arguing that all the kicking and offside rules are too tough and only made for men (Bierach and Thorborg, 2006: 43).

Counter-narratives: "Think manager, think male" (Schein, 1975). Academic research often suggests that women's path to success is fraught with difficulties that are not within their own gift to resolve, neither with the help of confidence training nor by redoubling their effort. Women's advancement in a male-centric system seems to resemble a tight-rope walk, in which women might fall 
from grace at any moment by making the wrong behavioural or linguistic move as they are faced with deeply engrained gender prejudices and cultural behaviour expectations. Banyard (2011: 8) claims that indeed "at some point in human history the concept of female inferiority was woven into the very fabric of how we see ourselves, how we treat each other, and how we organise society."

Virginia Schein, work- and organizational psychologist, has confirmed managerial sex typing as a major psychological barrier to the advancement of women ("think manager-think male") and a global phenomenon (Schein, 1973, 1975, 2001, 2007). Recent studies confirmed that women still struggle to break through the "glass ceiling"-a term coined in the 1980s-because of their difficulty in fitting into the prevailing male culture, and as a result are being treated as a minority group (Kaufman, 2008: 8). Newer metaphors include "glass cliffs" on which women are set up to fail, as they feel compelled to accept highly risky and highly visibly appointments which men might refuse (Ryan and Haslam, 2005), as well as the "labyrinth" (Eagly and Carli, 2007) that describes the obstacles women can expect to face at multiple points in their career.

Hakim's $(1996,2004)$ thesis of women looking upon work as a secondary activity has been critiqued widely (for example Bradley, 1996; Ginn et al, 1996; Crompton and Harris 1998; McRae, 2003 and Coleman, 2011).

Tutchell and Edmonds (2015: 176) have identified women's alleged lack of will and ambition as "a circular and perverse argument in the face of a mountain of evidence" that suggests women do not have the same opportunities. Wizorek has suggested that no "Lean In" or self-confidence coaching will help where predominantly discriminatory structures are at work (2014: 36). Aviva Wittenberg-Cox, founder of the gender consultancy 20-first has argued that "women are working far too hard at an issue actually beyond their power to solve. Corporate leaders must recognize that additional womendominated efforts are not the way to get companies to take the gender issue seriously" (Thomson and Laurent, 2015: 114). US academic Slaughter (2015: 16) believes that structural change is a necessary to complement individual effort: "Lean In tells you how to survive and win in what is still fundamentally a men's world, while making what changes you can when you reach the top. That is important, but much broader social, political and cultural change is also necessary. It cannot be achieved within the system, corporation by corporation, one progressive female CEO at the time".

Economists Gneezy et al. (2008) have revealed that societies are both subtly and overtly teaching females to behave and approach risk in certain ways, resulting in a socially constructed lack of competitiveness among women. Such factors can lead to a socially acceptable expressed lack of ambition by women, but does not mean women are unambitious or do not want a career.

Organisational psychologists Peters et al. (2013: 4) have analysed the so-called 'opt-out revolution' and found that women's lack of career ambition contributes to lack of representation at top levels; but rather than being biological or innate the observed differences "emerge as a consequence of subtle psychological processes related to stereotypes that are widely held about the characteristics of women, men and leaders". These include women's sense of dissimilarity to leader stereotypes ("think manager- think male"); a decade of evidence on the "glass cliff" (Ryan and Haslam, 2005), a metaphor which describes women in leadership positions that seem set up for failure ("think crisis-think female"; Ryan et al, 2011) and the fact that men get paid more money for equivalent work, which leads to lower satisfaction and motivation.

In many studies, gender stereotyping and the "male as norm" phenomenon stand out as a crucial inhibitor of women's progress to the top echelons of leadership (Durbin, 2016: 23, Catalyst, 2002). The definition of women as "minus-males" (Spender, 1985) has been perpetuated for centuries. In the 1980s, the linguist Dale Spender described women's structural problem with the "male-as-norm syndrome" in which women find it hard to occupy a positive space (Spender, 1985: 2). Aristotle, who according to the Encyclopaedia Britannica was the first genuine scientist in history-or according to Penny (2014: 113) a "vicious misogynist whom people have paid attention to for two thousand years"- saw women as inferior, incomplete, deformed males (Aristotle, 330 BC, History of Animals, Book IX quoted in Borghini, 2016). Medieval and early modern societies saw women as defective, less intelligent and less rational beings who were less able to control their passions and therefore prone to immorality. In the less distant past, Otto Weininger in his 1903 bestseller Geschlecht und Charakter (Sex and Character; Weininger, 1997) described the female aspect as passive, unproductive, unconscious, amoral and illogical. In 1949, De Beauvoir (1979: 25) wrote that legislators, priests, philosophers, and scholars have dedicated themselves to demonstrating that woman's subordinate role was wanted by the heavens and profitable to the earth. Durbin (2016: 24) claims that gender norms about women in society and the beliefs about women's role in society still work against women and that a masculine culture prevails.

Where men are perceived as "unencumbered" and "ideal" workers with "agentic" qualities, namely aggressive achievementorientation, women's commitment to work is questionedespecially if they are mothers. Women's "communal" and more relationship-centric styles are judged less suitable for powerful leadership positions (Durbin, 2016: 24-25 citing Rosener, 1990; Acker, 1990; Bass and Aviolo, 1997; Cockburn, 1991; Swanberg, 2004; Caleo and Heilman, 2014). Women are described as better decision-makers, problem-solvers, innovators, more empathic, more emotionally intelligent, more team-oriented, better at multitasking, less aggressive, more transformational and more effective leaders (Bierach and Thorborg, 2006; Eagly and Carli, 2007; Barsh, 2014). Men see these traits as non-essential in a top leader. A 2005 survey identified as "typically female" the ability to teamwork, diplomacy, humbleness, ability to form consensus and face conflict. $94 \%$ of male leaders who responded were convinced that these qualities don't bring any benefit to an organization (Bierach and Thorborg, 2006: 12). Schein (2007) found that 20 years after her original research a large majority of British men still insisted that women do not have what it takes to be a successful manager. The research also revealed that leaders should be tough and decisive; the image of a male hero leading his men to victory is supported by a plethora of metaphors from the sporting and military arenas. Although in theory (Baecker, 2014), the heroic leadership model centred on personality cult and charisma has been challenged, recent research (Rojo and Esteban, 2003: 245; Singh et al., 2006) suggests that it is still alive in the form of role models, in training materials and everyday organizational discourses (see Baxter, 2010: 26).

According to academics across multiple disciplines, cultural expectations of how women are supposed to behave are fundamental to answering questions of female leadership and power. Sociologist Pierre Bourdieu (2001) has analysed the power differential between men and women as the result of an inseparable interaction between the individual and society. Political scientist Marieke Looman (2011) refers to him when she claims that the androcentric view of the world is constantly self-justifying through its practices, for example the "natural" behaviours and body language expected of a woman, such as smiling, looking bashfully at the ground, tolerating interruptions, or taking small and fast steps (2010: 11). Recent research (Catalyst, 2007; Looman, 2011: 18; Tannen, 2016) has emphasised 
the notion of "double-bind" in which women with access to positions of power find themselves: if they act like men they question men's natural birth right to hold the position of power and this threatens a loss of the necessary attributes of femininity, yet if they act like women they appear unsuitable and incompetent for the job. If a woman copies the behaviour of a typical alpha male she will not be liked; in a woman, such behaviour attracts a list of unpleasant labels ("hard bitch", "scary, bossy, (...) tough, mean, bullying, moody, irrational" (Baxter 2010: 15)) and her "femininity is routinely assailed" (Fels, 2004: $10)$, whereas if she adopts a softer manner she will not get what she wants and be perceived as weak and lacking in leadership ability (Tutchell and Edmonds 2015: 10; Williams, 2013). Robin Lakoff, author of the 1975 classic Language and Woman's Place, (Lakoff, 2004) explains that when women do not talk and act as we expect them to, they are bound to lose our trust. When a woman is assertive, makes demands or shows ambition-a behaviour acceptable in men-she is criticised or even penalised (Tutchell and Edmonds, 2015: 81).

In assessments, women receive more criticism and their behaviour is interpreted through a different lens; for example, they are described as "abrasive" where a man might be seen as "confident" (Wehrle, 2014; Snyder 2014). There is also substantial and consistent evidence that women receive less recognition than men, from pre-school all the way through to their professional career. Several studies show how items ascribed to a man are rated higher, and that women evaluators are as likely as men to downgrade items ascribed to women (Fels, 2004). Baitsch (2004: 7) found that the arguments on which men and women are recommended for leadership positions and the vocabulary used differs substantially. He concludes that one has to assume that language mirrors the patterns of observation and interpretation, and thus it follows that men and women are measured with different yardsticks even when they are being considered for identical roles. The double standards that apply to men and women show up in language: different words are used for men and women to describe identical behaviour, both in the United Kingdom and in Germany:

Men who put themselves forward at work are "assertive", women who do the same are more often "pushy" or "bossy"; men are "persistent" whereas women are "nagging"; men are "frustrated", women "upset". A man has a lot to say; a woman is "chatty". A man discusses the doings of his colleagues and rivals; a woman "gossips" (Johnson, 2016).

If a man makes demands in short and explicitly worded sentences it is interpreted as assertiveness. If a woman displays the same behaviour she is said to have a 'sharp tongue' or to be 'bitchy' ${ }^{14}$. (Henn, 2012: 195).

Numerous academics have argued that gendered discourses exist to underpin the attitudes and norms operating in an organization, and that organisations themselves can also be described as gendered, indeed are profoundly gendered (for example Acker, 1990; Calás and Smircic, 1991; Gherardi, 1995; Alvesson and Billing 1997; Bargiela-Chiappini and Harris, 1997; Gherardi et al., 2003; Thomas and Davies, 2005 quoted in Kelan, 2008, and Kanter, 1977). In her analysis of gendered discourses in management literature, Professor Elisabeth Kelan, 2008 has noted explicit masculinity, with standard managers showing up as male, white and heterosexual (for instance Ferguson, 1994, Gerhard et al. 1992) and the systematic use of the male pronoun (Alvesson and Billing 1997; Green et al. 2001), as well as implicit masculinity though the persistent use of sport metaphors or of linguistic constructions such as "penetrating markets" (Collinson and Hearn, 2005: 264 quoted in Kelan, 2008). Military expressions such as "leading a big battalion" or "talking to the troops" are common in business speak. People who chair meetings are called chairmen, whether they are women or men. Kelan (2008) concludes that "even before women enter the picture, management discourses are 'already male gendered'”. Linguist Judith Baxter (2010: 14) typifies male-dominated, gender-divided and gender-multiple organisations, which are "talked into being" as products of gendered discourses which are then systematically reproduced to maintain this social construction of reality. Language, discourse and images inside organisations are loaded with expressions that attempt to perpetuate gender division and sexist clichés, claims academic Sarrió (according to Kaufman, 2008: 52). Women also have to develop "a special kind of linguistic expertise in order to be viewed positively as effective leaders" (Baxter 2010: xii) and strike a tone which does not contrast uncomfortably with masculine business norms (Baxter 2010: 150). In doing so, women have to employ a language which is "not of their own making" (Spender, 1985: 12). Men tend to use language to command and control, "asserting their dominance through verbosity, name-dropping, subtle or overt boasting, and entertainment strategies such as jokes and anecdotes" (Baxter 2010: 18). Women are expected to listen, agree, support and be amused, certainly not to interrupt, challenge male authority or upset the status quo.

In 2010, Germany's Federal Department for Family, Elderly, Women and Youth published a representative study of 511 male and female leaders which revealed "massive informal and cultural bulwarks against women with different and overcrossing mentality patterns acting as barrier and lock"15 (Wippermann, 2010: 8). Three dominant mentality types emerged as "guardians of the glass ceiling"16 in Germany. These are: 1) the type that excludes women on social-conservative grounds, postulating that a leader needs a stable family background and orderly conditions and critiquing women as "grim lone fighters" if they try to surpass men by "overcompensating" male behaviour; 2) a pseudo-emancipated mentality, in principle open to equality and women in middle management, but constructing women as unsuited to the "different sport" of top management because of gender role expectations (women would come across as unfeminine and damage company image and brand); 3) the gender-blind individualistic attitude that bemoans a lack of authentic and flexible women in the market. Typically, all these mentality types are represented in a company, creating multidimensional barriers as women cannot meet all expectations simultaneously.

\section{Conclusions}

The situation in Britain and Germany is remarkably similar. That may seem unsurprising, given the two countries share the same "collective programming of the mind" when it comes to two important dimensions of national culture as defined by academics Hofstede and Hofstede (2005: 43, 46, 120-121): power distance ("the extent to which less powerful members of organisations expect and accept that power is distributed unequally") and masculinity ("emotional gender roles are clearly distinct: men are supposed to be assertive, tough, and focused on material success, whereas women are supposed to be more modest, tender and concerned with the quality of life"). In both countries, current efforts and debate are centred on women on Boards, who hold governance roles, rather than decision-making powers. "Nonexecutive directors play an important role as the guardians of values, challenging decisions and managing risk. But it is the job of executives - the sleeves-rolled-up leaders in our society-to run organisations on a daily basis. We don't have enough women who 
are executive leaders in the United Kingdom-the CEOs, the CFOs, the heads of operating divisions, the MDs and partners" (Carolyn Fairbairn, Director General of the Confederation of British Industry in Vinnicombe et al, July 2016). The general consensus in Germany and Britain (and across Europe) has been that when women hold $25 \%$ of non-executive roles, that indicates gender parity success-only in mid-2016 was the UK target adjusted to " $33 \%$ by 2020 ". In Germany, the March 2015 ratification of a $25 \%$ female quota (Frauenquote) for supervisory Boards has stirred controversy. The end of all-male FTSE 100 Boards and the achievement of $26.1 \%$ female NEDs (in FTSE 100 companies only, and only on average) in late 2015 was cause for great celebration by the government (Lord Davies, 2015); even though all it took was for each of the FTSE 100 companies to appoint one additional woman to their Board within a 4-year time frame, and even though only just over half of FTSE 100 boards had actually met or exceeded the target by October 2015 . The effort has also led to a sharp reduction in the number of women in Executive Committees in the United Kingdom holding real decision-making mandates (Thomson and Laurent, 2015: 157). Even the most strident proponents of gender parity are curtailing their ambition to 40:60 at best (30\% Club, Wolf, 2013; Thomson and Laurent, 2015). They are betting on "diplomacy and negotiation, rather than force majeure" and on complimenting "senior members of the business elite willing to engage in conversation" into throwing a little weight behind greater parity: "it is hard to exaggerate the importance of the willingness of these very distinguished business people to give a helping hand to able women as they climb up the last few rungs of organizational hierarchies" (Thomson and Laurent, 2015: 10-11). In this context, it appears important not to remove too much privilege from men. An example is the sharp increase in the number of Non-Executive roles on FTSE 100 Boards since 1999, which made it easier to appoint $25 \%$ of women without replacing too many men already in post. De Beauvoir (1979: 21) remarked on this phenomenon that the feminist movement has never been more than a symbolic agitation, in which women have only won what men were prepared to concede; they took nothing: they were given things ${ }^{17}$.

The findings presented above indicate first of all a widely held belief in both Germany and Britain that the struggle for gender equality is effectively over. Yet the statistics tell a different story, and suggest that we have not come as far as popular discourses suggest. A new generation of feminists is speaking out, claiming that gender equality continues to be one of the most urgent and relevant social justice campaigns today.

Second, the key case put forward in favour of gender parity is that having more women in leadership positions is advantageous both for individual companies and for the economy at large. However, no great shifts have been noted at the very top of organizations since that economic argument was first made around a decade ago. In addition, academic evidence appears to not underpin the claims made by Catalyst, McKinsey, the Davies report and numerous journalists, that more women means better financial results. Meta-studies and several meta-analyses have shown the correlation is at best extremely small. Eagly (2016) worries that gender parity advocates (for example Catalyst, 2004; Desvaux et al. 2007 and 2010) have used social science data in a selective and inaccurate way, and that the business case put forward by advocacy and consulting firms does not meet the standards of economics and management disciplines:

these studies would certainly not be publishable in academic journals because of the elementary form of their data presentations. [...] Does it matter that the studies are academically substandard? The answer to this question is an emphatic yes. Statistically trained investigators, and perhaps even students who have had one or two statistics courses, would recommend at least the presentation of correlation. (Eagly, 2016: 201)

Yet their "findings" are referred to in media and government reports (for example Vinnicombe et al. 2016: 30) as "delivering unassailable proof that accelerating women's advancement in the workplace produces better outcomes" (Women's Business Council, 2013). If the business case for parity is indeed unreliable, does it follow that gender parity is not worthwhile? A number of writers (Kreissl, 2000; Banyard, 2011; Penny, 2014; Foster, 2016; Eagly, 2016; Tutchell and Edmonds, 2015; Slaughter, 2015) have deplored the absence of social justice arguments, an overemphasis on capitalist principles of shareholder value and the incompleteness of the narrative which focuses on educated, middle-class, heterosexual, white women. Working class and underprivileged women feature as invisible mass of cleaners and nannies, enabling "modern woman" to pursue her career (Kreissl, 2000). There is no mention of those for whom opting out is financially not an option, of LGBT, or of women of colour. In this context, the business case narrative has been dismissed as "corporate feminism" (Foster, 2016, Penny, 2014).

Finally, a much touted reason for female underrepresentation in leadership is women's own choices. It is claimed that they lack the ambition and appetite for power and need to grow in confidence: any woman willing to work hard can make it to the top. However, there is evidence that the stark absence of women in positions of power cannot be blamed on individual failure. Rather, women face a "complex of difficulties that are related and in some cases overlap" (Tutchell and Edmonds 2015: 14) and their advancement in quintessentially androcentric environments resembles a tight-rope walk as they are faced with deeply engrained gender prejudices and cultural behaviour expectations.

Statistics and empirical and anecdotal evidence suggest that the prospects of gender equality at the top occurring in our lifetime are dismal. In spite of this, the dominant narratives-which are rarely evidence-based-optimistically put forward the notion that we are on the right track. "Societies tell themselves necessary fictions in the same way that individuals and families do," writes Wolf, citing Ibsen ("Henrik Ibsen called them 'vital lies' "), and psychologist Daniel Goleman: "the collusion is maintained by directing attention away from the fearsome fact, or by repackaging its meaning in an acceptable format" (Wolf, 1991: 17). These stories have an impact on individual identities, possibilities and ambitions, and contribute to the collective discourses that shape a cultural atmosphere. They are impossible to escape and difficult not to collude in. German writer Morgner (2011: 93) famously noted that women do not only live in patriarchy; it also lives within them ${ }^{18}$. It appears indeed difficult to progress into senior leadership in a system without being part of it, subscribing to its rules, value and stories: Kreissl $(2000: 128,156)$ writes that "every open or intense attack on the current status quo results in exclusion from the circle of serious contemporaries" 19 .

The dominant discourse seems designed to reassure those in power that the lack of women in top positions is not owed to their actions (or lack thereof). It tells us that cognitive dissonances can be reframed with positive psychology. It offers women self-help advice on how to win, individually, within a quintessentially androcentric and misogynist cultural atmosphere. That makes the ideal modern career woman a "neo-liberal hero triumphing on the markets' own terms without overturning any hierarchies" (Penny, 2014: 3). The appeal of such narratives is plain: people want to hear that they can change things; that "the fate of their careers and families is within their control. [...] It's the message any young person coming out of school and looking forward to her life wants to hear. It's the reason that optimists do better in 
life than pessimists. It's the source of both hope and resilience"; Slaughter (2015: 14) likens the principle to the American Dream. It lets a small number of outliers through, while keeping the rest in place and in hope.

\section{Notes}

$1 \mathrm{I}$ am conscious that it is not possible, in a piece of this length, to cover other important arenas for women's leadership such as politics, academia, or the military; nor to give an assessment of the (equally important) discourses on motherhood, family, sex, or appearance.

2 "nicht nur einen weiten Weg zurückgelegt, sondern mehrfach die Welt umrundet"

3 "Wir sind doch schon am Ziel [...] Frauen dürfen wählen gehen? Check! Sie dürfen studieren? Check! Sie können ihr eigenes Geld verdienen? Check! Frauen können das politisch mächtigste Amt erreichen und Bundeskanzlerin werden? Check!”

4 Germany's official national census

5 Ein bisschen gleich ist nicht genug! Warum wir von Geschlechtergleichheit noch weit entfernt sind (Domscheit-Berg, 2015)

6 Aufschrei

7 "Es gibt sicher in der Frauenfrage bei uns noch einiges zu tun. Aber eine besonders gravierende, flächendeckende Fehlhaltung von Männern gegenüber Frauen kann ich hierzulande nicht erkennen"

8 "große Rhetorik für große Vorhaben, vordergründige Verneigung vor der großen Überzeugung, Auszeichnungen für Aktivitäten ohne entsprechende Resultate, hinterrücks stille Missachtung, Vergessen, unbewusstes Ausblenden, subtile Sabotage oder Akzeptanz der Nichtveränderung".

9 "Nur weil ich eine Frau bin, stehe ich für Frauenthemen? Hallo, Leute, ich habe Geschichte und Politik studiert, mein Steckenpferd waren Internationale Beziehungen und Außenpolitik. Hackt's? Ich habe fünf Jahre bei Financial Times Deutschland gearbeitet, Titel wie Beef und National Geographic verantwortet - alles 'Jungs-Titel'. In die Gedöns-Ecke werde ich erst geschoben, seit ich im Vorstand sitze”.

10 Sandberg (2013)

11 At a 2016 women's day conference in the UK (see WICT, 2016) a speaker shared her "touchstones of leadership" for "brushing shards out of their hair"; her top tips included "know yourself, communicate, listen, be fearless".

12 He has since resigned, following pressure from the Board of Saatchi \& Saatchi's parent company, Publicis Groupe.

13 "Dämlich, weil sie sich nicht einfach nehmen, was ihnen zusteht. Faul, weil ihnen der stete Ringkampf um Projekte, Budgets und Personal spätestens mit Mitte $30 \mathrm{zu}$ anstrengend wird, und zu politisch. Unaufrichtig, weil sie nicht zugeben, dass sie sich freiwillig ins Privatleben zurückziehen, sondern die so genannte Glasdecke vorschieben"

14 "Wenn ein Mann Forderungen in kurzen Sätzen deutlich formuliert, wird das als Durchsetzungsstärke interpretiert. Wenn eine Frau genauso auftritt, heißt es, dass sie 'Haare auf den Zähnen' habe bzw. 'bissig' sei.”

15 "In den von Männern dominierten Führungsebenen der Wirtschaft gibt es seitens der Männer massive informelle und kulturelle Bollwerke gegenüber Frauen. Hier wirken verschiedene miteinander verschränkte Mentalitätsmuster als Barriere und Sperriegel"

16 "Hüter der gläsernen Decke"

17 “L'action das femmes n’a jamais été qu'une agitation symbolique; ells n’ont gangé que ce que les hommes ont bien voulu leur conceder; elles n'ont rien pris: elles ont reçu."

18 "Frauen leben nicht nur im Patriarchat, es lebt auch in ihnen"

19 "Jede offene und intensive Attacke auf den herrschenden Status quo wird mit Ausschluss aus dem Kreis der ernst zu nehmenden Zeitgenossen geahndet"

\section{References}

Abbott LJ, Parker S and Presley TJ (2012) Female board presence and the likelihood of financial restatement. Accounting Horizons; 26 (4): 607-629.

Acker J (1990) Hierarchies, jobs, bodies: A theory of gendered organisation. Gender and Society; 4 (2): 139-158.

Adams RB and Ferreira D (2009) Women in the boardroom and their impact on governance and performance. Journal of Financial Economics; 94 (2): 291-309.

Adler R (2009) Profit, thy name is ... woman? Pacific Standard. https://psmag.com/ profit-thy-name-is-woman-2a38e799a87a\#.r20ts04g8.

Aguirre D and Sabbagh K (2010) The Third Billion. Strategy+Business. http://www. strategy-business.com/article/10211?gko $=98895$.

Allan K (2016) Gender pay gap: women earn $£ 300,000$ less than men over working life. The Guardian. http://gu.com/p/4hb6x?CMP = Share_iOSApp_Other.

Alvesson M and Billing YD (1997) Understanding Gender and Organisations. Sage: London.

Anonymous. (2015) Riesige Gehaltslücke: Diese Jobs sollten Frauen lieber nicht ergreifen. Focus. http://www.focus.de/finanzen/karriere/perspektiven/frauen/ bis-zu-37-prozent-unterschied-in-diesen-berufen-sind-frauen-am-staerkstenbenachteiligt_id_4530618.html.

Baecker D (2014) Postheroische Führung-Vom Rechnen mit Komplexität. Springer: Heidelberg.
Baitsch C (2004) Wenn zwei das Gleiche tun...Zum Einfluss unterschiedlicher Wahrnehmung von Männern und Frauen auf die Personalbeurteilung. Senat der Freien und Hansestadt Hamburg. Behörde für Soziales und Familie. http:// www.hamburg.de/contentblob/118366/b231cb5b0fa17c4e38c60ac35a1871af/ data/personalpolitik-5.pdf.

Banyard K (2011) The Equality Illusion: The Truth about Women and Men Today. Faber \& Faber: London.

Bargiela-Chiappini F and Harris S (1997) Managing Language: The Discourse of Corporate Meetings. John Benjamins: Amsterdam and Philadelphia.

Barsh J (2014) Can women fix capitalism? McKinsey Quarterly. http://www. mckinsey.com/insights/leading_in_the_21st_century/can_women_fix_capital ism

Barter C, McCarry M, Berridge D and Evans K (2009) Partner exploitation and violence in teenage intimate relationships. NSPCC. https://www.nspcc.org.uk/ globalassets/documents/research-reports/partner-exploitation-violence-teen age-intimate-relationships-report.pdf.

Bass BM and Aviolo BJ (1997) Shatter the glass ceiling: Women make better managers. In: Grint K (ed) Leadership: Classical, Contemporary and Critical Approaches. Oxford University Press: Oxford.

Bates L (2014) Everyday Sexism. Simon \& Schuster: London.

Baxter J (2010) The Language of Female Leadership. Palgrave Macmillan: London. De Beauvoir S (1979) Le deuxième sexe I. Gallimard: Paris, France.

Belkin L (2003) The opt out revolution. New York Times Magazine. http://www. nytimes.com/2003/10/26/magazine/26WOMEN.html?pagewanted = all.

Bierach B (2002) Das dämliche Geschlecht. Wiley-VCH Verlag: Darmstadt, Germany.

Bierach B and Thorborg H (2006) Oben Ohne. Warum es keine Frauen in Chefetagen gibt. Econ: Berlin.

Bielby C and Matthes F (2015) Gender and sexuality. In: Colvin S (ed) The Routledge Handbook of German Politics and Culture. Routledge: Oxon, UK, pp 250-267.

Borghini A (2016) Plato and Aristotle on Women: Selected Quotes. About Education. http://philosophy.about.com/od/Philosophical-Quotes-and-Lines/a/ Plato-And-Aristotle-On-Women-Selected-Quotes.htm.

Bourdieu P (2001) Masculine domination. Polity: Cambridge.

Bradley H (1996) Fractured Identities: Changing Patterns of Inequality; Cambridge: Polity.

Brennan B (2015) Top 10 Things Everyone Should Know About Women Consumers. Forbes. http://www.forbes.com/sites/bridgetbrennan/2015/01/21/ top-10-things-everyone-should-know-about-women-consumers/\#7858b252 $897 \mathrm{~d}$.

Bruner J (2004) The narrative creation of self. In: Angus LE and McLeod J (eds) The Handbook of Narrative and Psychotherapy. Practice, Theory and Research. Sage: London, pp 3-15.

Butler J (2005) Giving an Account of Oneself. Fordham University Press: New York.

Calás MB and Smircic L (1991) Re-writing gender into organizational theorizing. Directions from feminist perspectives. In: Reed $M$ and Hughes $M$ (eds) Rethinking Organization. New Directions in Organization Theory and Analysis. Sage: London, pp 227-253.

Caleo S and Heilman ME (2014) Is this a man's world? Obstacles to women's success in male-typed domains. In: Burke RJ and Major DA (eds) Gender in Organisations: Are Men Allies or Adversaries to Women's Career Advancement. Edward Elgar: Cheltenham, UK, pp 217-233.

Cambridge Business School. (4 January 2017) Are you a female millennial with ambition? Start planning for the top job now. http://insight.jbs.cam.ac.uk/2017/ ambitious-female-millenials/.

Carter NM and Wagner HM (2011) The Bottom line: Corporate Performance and women's Representation on Boards 2004-2008. Catalyst: New York.

Catalyst. (2002) Women in Leadership: European Business Imperative. Catalyst: New York.

Catalyst. (2004) The Bottom Line: Corporate Performance and Women's Representation on Boards; Catalyst: New York.

Catalyst. (2007) The Double-Bind Dilemma for Women in Leadership: Damned if You Do, Doomed if You Don't. Catalyst: New York.

Catalyst. (2013) Why Diversity Matters. Catalyst: New York.

CMI. (2013) Women in Leadership. White Paper. Chartered Management Institute: London.

Coates J (2012) The Hour between Dog and Wolf: Risk Taking, Gut Feelings and the Biology of Boom and Bust. Random House: London.

Cochrane K (2013) All the Rebel Women: The Rise of the Fourth Wave of Feminism. Guardian Shorts: Kindle.

Cockburn C (1991) In the Way of Women: Men's Resistance to Sex Equality in Organizations. Macmillan Education: London.

Codd E and Lewis H (2016) Technology, career pathways and the gender paygap. Women in Science, Technology, Engineering and Mathematics (STEM). Deloitte. http://www2.deloitte.com/uk/en/pages/growth/articles/technologycareer-pathways-gender-pay-gap.html.

Coleman M (2011) Women at the Top. Challenges, Choices and Change. Palgrave Macmillan: London. 
Collinson DL and Hearn J (2005) Men and masculinities in work, organizations and management. In: Kimmel MS, Hearn J and Connell RW (eds) Handbook of Studies on Men \& Masculinities. Sage: London, pp 289-310.

Credit Suisse Research Institute. (2012) Gender Diversity and Corporate Performance. Credit Suisse AG: Zurich.

Criado-Perez C (2015) Do it Like a Woman... and Change the World. Portobello Books: London.

Crompton R and Harris F (1998) A reply to Hakim. British Journals of Sociology; 48 (1): 144-149.

Deleuze G and Guattari F (1980) Mille plateaux. Capitalisme et schizonphrénie 2. Les Éditions de Minuit: Paris, pp 9-27.

Deszo C and Ross D (2008) When Women Rank High, Firms Profit. Columbia Business School Ideas at Work: New York.

Desvaux G, Devillard-Hoellinger S and Baumgarten P (2007) Women Matter: Gender Diversity, a Corporate Performance Driver. McKinsey \& Company: Paris, France.

Desvaux G, Devillard S and Sancier-Sultan S (2010) Women matter 2010: Woman at the Top of Corporations: Making it Happen. McKinsey \& Company: Paris, France.

Domscheit-Berg A (2015) Ein bisschen gleich ist nicht genug! Warum wir von Geschlechtergleichheit noch weit entfernt sind. Ein Weckruf. Wilhelm Heyne: München, Germany.

Dössel C (19 May 2010) Teile und herrsche. Süddeutsche Zeitung. http://www. sueddeutsche.de/kultur/die-frauenquote-in-der-politik-teile-und-herrsche-1. 894078.

Drescher F and Schrott P (2015) Einflussfaktoren auf die Einstellung zur Frauenquote. WSI-Mitteilungen 2. http://www.boeckler.de/wsi-mitteilungen_ 53168_53184.htm

Durbin S (2016) Women who Succeed. Strangers in Paradise?. Palgrave Macmillan: London.

Eagly A (2016) When passionate advocates meet research on Diversity, does the honest broker stand a chance? Journal of Social Issues. Special Issue: Ageism: Health and Employment Contexts; 72 (1): 199-222.

Eagly A and Carli L (2007) Women and the labyrinth of leadership. Harvard Business Review. https://hbr.org/2007/09/women-and-the-labyrinth-of-leadership.

Echtermaier B (12 Aug 2014) Das verstehen wir nicht. Warum sind Frauen antifeministisch? Brigitte. http://www.brigitte.de/frauen/gesellschaft/antifeminis tisch-1207563/.

Edelburg K (2012) How to Play the Game? Erfolgreich als Frau in einer maskulinen Geschäftswelt. Schardt: Berlin.

Emcke C (11 March 2016) Nein. Man stelle sich vor, ein Raub zählte nur als Verbrechen, wenn die Opfer sich dagegen gewehrt hätten. Undenkbar! Aber das Sexualstrafrecht ist so konzipiert. Süddeutsche Zeitung. http://www.sued deutsche.de/politik/kolumne-nein-1.2902763.

Eurostat. (7 March 2016) Report on Equality between Women and Men in the EU. European Commission-Justice and Consumers: Vilnius, Lithuania.

European Commission. (2012) Women on Boards. Fact sheet- 1. The economic arguments. European Commission-Justice and Consumers: Vilnius, Lithuania, http://ec.europa.eu/justice/gender-equality/files/womenonboards/factsheet-gen eral-1_en.pdf.

Fels A (2004) Do Women Lack Ambition? Harvard Business Review. https://hbr. org/2004/04/do-women-lack-ambition.

Ferguson KE (1994) On bringing more theory, more voices and more politics to the study of organizations. Organization; 1 (1): 81-99.

Fidelio Partners. (2016) Fidelio to host third "a seat at the table" programme for senior female executives in September 2016. Press release. http://fideliopartners. com/2016/03/24/press-release-fidelio-to-host-third-a-seat-at-the-table-programmefor-senior-female-executives-in-september-2016/.

Fiske ST and Lee TL (2008) Stereotypes and prejudice create workplace discrimination. In: Brief AP (ed) Diversity at Work. Cambridge University Press: Cambridge.

Foucault M (1970) The Order of Things: An Archaeology of Human Sciences. Vintage Books: New York.

Foster D (2016) Lean Out. Repeater: London.

Frankel LP (2005) Nice Girls Don't Get the Corner Office: 101 Unconscious Mistakes. Business Plus: New York.

Gatrell C and Swan E (eds) (2008) Gender and diversity. In: Management: A Concise Introduction. Sage: London.

Gerhard B, Osterloh M and Schmid R (1992) (Wie) Kommen Frauen in deutschsprachigen Personallehrbüchern vor. In: Krell G (ed) Personalpolitik aus der Sicht von Frauen-Frauen aus der Sicht der Personalpolitik: was kann die Personalforschung von der Frauenforschung lernen?. Hampp: München, Germany, pp 28-49.

Gherardi S (1995) Gender, Symbolism and Organisational Culture. Sage: London.

Gherardi S, Marshall J, Mills AJ (2003) Theorizing gender and organizing. In: Westwood R and Clegg S (eds) Debating Organization-Point-Counterpoint in Organization Studies. Blackwell: Oxford.

Green L, Parkin PW and Hearn J (2001) Power. In: Wilson EM (ed) Organizational Behaviour and Gender. Sage: London, pp 188-214.
Gini A (2001) My Job My Self: Work and the Creation of the Modern Individual. Routledge: London.

Ginn J et al (1996) Feminist fallacies. A reply to Hakim on women's employment and whose myths are they anyway: A comment. British Journal of Sociology; 47 (2): 167-177.

Gneezy U, Leonard KL and List AJ (2008) Gender Differences in Competition: Evidence from a Matrilineal and a Patriarchal Society. National Bureau of Economic Research: Cambridge, MA.

Gratton L, Kelan E, Voigt A, Walker L and Wolfram H-J (2007) Innovative Potential: Men and Women in Teams. Lehman Brothers Centre for Women in Business at the London Business School: London, http://www.london.edu/ assets/documents/Word/Innovative_Potential_NOV_2007.pdf.

Haas D (10 March 2016) Gib den Wolken Zucker. Dürftiger Plot, nervige Figuren. Dennoch ein exzellenter Text. "Wir kommen", das Romandebüt von Ronja von Rönne. Die ZEIT; 12, 45.

Hakim C (1996) Female Heterogeneity and the Polarisation of Women's Employment. The Athlone Press: London.

Hakim C (2004) Key Issues in Women's Work: Female Diversity and the Polarisation of Women's Employment. The Athlone Press: London.

Hakim C (2012) Feminist Myths and Magic Medicine. The Flawed Thinking Behind Calls for Further Equality Legislation. Centre for Policy Studies, London School of Economics: London.

Häming A and Tietz J (2012) Manager spielen ist beknackt. Taz. http://www.taz.de/ 1/archiv/digitaz/artikel/?ressort $=$ hi\&dig $=2012 \% 2 \mathrm{~F} 11 \% 2 \mathrm{~F} 17 \% 2 \mathrm{Fa} 0108 \& \mathrm{cHash}$ =338f4959f5fb7ce5f6929e0a9a57fdf7.

Henn M (2012) Die Kunst des Aufstiegs. Was Frauen in Führungspositionen kennzeichnet. Campus: Frankfurt.

Herring C (2009) Does diversity pay? Race, gender, and the business case for diversity. American Sociological Review; 72 (6): 895-914.

Hill E (Oct 2015) Feminism is over, the battle is won. Time to move on. The Spectator. http://www.spectator.co.uk/2015/10/the-decline-of-feminism/.

Hofstede G and Hofstede GJ (2005) Cultures and Organizations. Software of the Mind. Intercultural Cooperation and Its Importance for Survival; LondonMcGraw-Hill.

HM Government Equality and Human Rights Commission. (2016) Pregnancy and maternity-related disadvantage and discrimination. https://www.gov.uk/govern ment/uploads/system/uploads/attachment_data/file/509500/BIS-16-145-preg nancy-and-maternity-related-discrimination-and-disadvantage-summary.pdf.

Institute of Leadership and Management. (2011) Ambition and Gender at Work. ILM: London.

Joecks J, Pull K and Vetter K (2013) Gender diversity in the boardroom and firm performance: What exactly constitutes a "critical mass?"? Journal of Business Ethics; 118 (1): 61-72.

Johnson. (13 Feb 2016) Double-edged words: The secret meaning of 'feisty'. The economist: http://www.economist.com/news/books-and-arts/21692842-secretmeaning-feisty-double-edged-words.

Joy L, Carter NM, Wagner HM and Narayanan S (2007) The Bottom Line: Corporate Performance and Women's Representation on Boards. Catalyst: New York.

Kanter RM (1977) Men and Women of the Corporation. Basic Books: New York.

Kaufman AE (2008) Women in Management and Life Cycle. Aspects that Limit or Promote Getting to the Top. Palgrave Macmillan: London.

Kelan E (2008) The discursive construction of gender in contemporary management literature. Journal of Business Ethics; 81 (2): 427-445.

Kelan E (2012) Rising Stars: Developing Millennial Women as Leaders. Palgrave Macmillan: London.

Knaths M (2009) Spiele mit der Macht: Wie Frauen sich durchsetzen. Piper: München. Kotiranta A, Kovalainen A and Rouvinen P (24 Sept 2007) Does female leadership boost firm profitability? EVA Analysis. http://www.eva.fi/wp-content/uploads/ files/2133_Analyysi_no_003_eng_FemaleLeadership.pdf.

Kreissl R (2000) Die ewige Zweite. Droemer Verlag: München, Germany.

Lakoff RT (2004) Language and Woman's Place. Text and Commentaries. Oxford University Press: Oxford.

Looman M (2011) Am Rande der Macht. Frauen in Deutschland in Politik und Wirtschaft. Budrich Uni Press: Opladen, Germany.

Lord Davies of Abersoch M. (October 2015) Improving the Gender Balance on British Boards. Women on Boards Davies review five-year summary. HM Government. https://www.gov.uk/government/uploads/system/uploads/attach ment_data/file/482059/BIS-15-585-women-on-boards-davies-review-5-yearsummary-october-2015.pdf.

Lorenzo R, Rentmeister H, Schetelig K, Zawadzki A and Dyrchs S (2016) Frau Dich! Das schlummernde Potenzial der Frauen für die deutsche Wirtschaft. Boston Consulting Group. http://www.bcg.at/documents/file205056.pdf.

Maier M (1999) On the gendered substructure of organisations. Dimensions and dilemmas of corporate masculinity. In: Powell G (ed) The Handbook of Gender. Sage Publications: Thousand Oaks, CA.

Mascolo G and von Hammstein K (2013) "Ich übe noch". Der Spiegel 10/2013. http://www.spiegel.de/spiegel/print/d-91346549.html. 
Mattis MC (1993) Women directors progress and opportunities for the future. Business and the Contemporary World; 5 (3): 140-156.

Mavin S (2006) Expectations of women in leadership and managementadvancement through solidarity?. In: McTavish D and Miller K (eds) Women in Leadership and Management. Edward Elgar: Cheltenham, UK, pp 71-88.

McInerney-Lacombe N, Billiomoria D and Salipante PF (2008) Championing the discussion on tough issues: How women corporate directors contribute to board deliberation. In: Vinnicombe S et al (eds) Women on Corporate Boards of Directors: International Research and Practice. Edward Elgar: Cheltenham, UK, pp 123-139.

McRae S (2003) Constraints and choices in mothers' employment careers. Considering of Hakim's preference theory. British Journal of Sociology; 54 (3): 317-338.

McTavish D and Miller K (2006) Women in Leadership and Management. Edward Elgar: Cheltenham, UK.

Mika B (2012) Die Feigheit der Frauen. Rollenfallen und Geiselmentalität. Eine Streitschrift wider den Selbstbetrug. Goldmann: München, Germany.

Morgner I (2011) Amanda, Ein Hexenroman. Btb: München, Germany.

Och A and Daniels K (2013) Lust auf Macht. Wie (nicht nur) Frauen an die Spitze kommen. Linde International: Wien, Austria.

O'Reilly L (2016) Saatchi \& Saatchi chairman Kevin Roberts thinks the gender diversity in advertising debate is 'over'. Business Insider. http://uk.businessinsi der.com/kevin-roberts-on-women-in-leadership-roles-2016-7? $\mathrm{r}=\mathrm{US} \& \mathrm{IR}=\mathrm{T}$.

Owen R (10 May 2015) CIPD daily bulletin.

Penny L (2014) Unspeakable things. Sex, lies and revolution. Bloomsbury: London.

Peters K, Ryan M, Haslam A and Morgenroth T (2013) The psychology and economics of women in leadership. European Parliament Policy Department C. http://www.europarl.europa.eu/RegData/etudes/workshop/join/2013/474408/ IPOL-FEMM_AT(2013)474408_EN.pdf.

Pletzer JL, Nikolova R, Kedzio KK and Voelpel SC (2015) Does gender matter? Female representation on corporate boards and firm financial performance-A meta-analysis. Plos One. http://dx.doi.org/10.1371/journal.pone.0130005.

Post C and Byron K (2015) Women on boards and firm financial performance: A meta-analysis. Academy of Management Journal; 58 (5): 1546-1571.

Rindfleish J (2000) Senior management women in Australia: Diverse perspectives. Women in Management Review; 15 (4): 172-80.

Rosener JB (1990) Ways women lead. Harvard Business Review; 63 (Nov/Dec): $119-125$.

Rhode B and Kellerman DL (2007) Women \& Leadership. The State of Play and Strategies for Change. Wiley \& Sons: San Francisco.

Richardson L and Adams St. Pierre E (2005) Writing: A method of inquiry. In: Denzin NK and Lincoln YS (eds) The Sage handbook of qualitative research, 3rd edn, Sage: London, 959-978.

Rojo RM and Esteban CG (2003) Discourse at work: when women take on the role of manager. In: Weiss G and Wodak R (eds) Critical Discourse Analysis: Theory and Interdisciplinarity. Palgrave: Basingstoke.

Rosin H (2012) The End of Men: And the Rise of Women. Viking: London.

Ryan MS and Haslam A (2005) The glass cliff: Evidence that women are overrepresented in precarious leadership positions. British Journal of Management; 16 (2): 81-90.

Ryan MS, Haslam A, Herbsy M and Bongiorno R (2011) Think crisis-think female: The glass cliff and contextual variation in the think manager-think male stereotype. Journal of Applied Psychology; 96 (3): 470-84.

Sandberg S (2013) Lean In: Women, Work, and the Will to Lead. Random House: New York.

Sattelberger T (2011) Praxisbeispiel Telekom: Die Frauenquote-Qual der Entscheidung und der schwierige Weg vor uns. In: Krell G (ed) Chancengleichheit durch Personalpolitik. Gabler Verlag: Wiesbaden, Germany.

Schein VE (1973) The relationship between sex role stereotypes and requisite management characteristics. Journal of Applied Psychology; 57, 95-100.

Schein VE (1975) The relationship between sex role stereotypes and requisite management characteristics among female managers. Journal of Applied Psychology; 60, 340-344.

Schein VE (2001) A global look at psychological barriers to women's progress in management. Journal of Social Issues; 57 (4): 675-688.

Schein VE (2007) Women in management: Reflections and projections. Women in Management Review; 22 (1): 6-18.

Schneider B (2011) Fleißige Frauen arbeiten, schlaue steigen auf: Wie Frauen in Führung gehen. Goldmann: München, Germany.

Schumpeter. (6 June 2015) Sex in the boardroom. Claims that women manage differently from - or better than - men are questionable. The economist.

Silverstein MJ and Sayre K (Sept 2009) The Female Economy. Harvard Business Review. https://hbr.org/2009/09/the-female-economy.

Singh V, Vinnicombe S and James K (2006) Constructing a professional identity: how young female managers use role models. Women in management review; 21 (1): $67-81$.
Slater and Gordon. (2013) Sexual Harassment Rife in the Workplace: New Study Reveals. http://www.slatergordon.co.uk/media-centre/press-releases/2013/10/ sexual-harassment-rife-in-the-workplace-new-study-reveals/.

Slaughter A (2015) Unfinished Business. Women Men Work Family. Oneworld Publications: London.

Snyder K (2014) The abrasiveness trap: High-achieving men and women are described differently in reviews. Fortune. http://fortune.com/2014/08/26/ performance-review-gender-bias/.

Solberg AG (2013) Male and female leadership styles. The British Psychological Society. http://www.bps.org.uk/news/male-and-female-leadership-styles.

Spender D (1985) Man Made Language. Thorsons: London.

Swanberg JE (2004) Illuminating gender organization assumptions: An important step in creating a family-friendly organization: A case study approach. Community, Work and Family; 7 (1): 3-28.

Tannen D (19 Feb 2016) Our impossible expectations of Hillary Clinton and all women in authority. The Washington Post. https://www.washington post.com/opinions/our-impossible-expectations-of-hillary-clinton-and-allwomen-in-authority/2016/02/19/35e416d0-d5ba-11e5-be55-2cc3cle4b76b_ story.html.

Terjesen S, Singh V and Vinnicombe S (2008) Do women still lack the 'right' kind of human capital for directorships on the FTSE 100 corporate boards? In: Vinnocombe $\mathrm{S}$ et al (eds) Women on Corporate Boards of Directors: International Research and Practice. Edward Elgar: Cheltenham, UK, pp 152-164.

Terjesen S and Singh V (2008) Female presence on corporate boards: a multicountry study of environmental context. Journal of Business Ethics; 83 (1): $55-63$.

Thomas R and Davies A (2005) What have the feminists done for us? Feminist theory and organizational resistance. Organization; 12 (5): 711-740.

Thomson P and Laurent C (2015) The Rise of the Female Executive. How Women's Leadership is Accelerating Cultural Change. Palgrave Macmillan: London.

TUC (9 Nov 2015) Gender pay gap for UK's top earners hits 55\%, says TUC. https://www.tuc.org.uk/equality-issues/gender-pay-gap-uk's-top-earners-hits55 -says-tuc.

Tutchell E and Edmonds J (2015) Man-Made. Why So Few Women Are in Positions of Power. Gower: Farnham.

Van Dijk H, van Engen ML and van Knippenberg D (2012) Defying conventional wisdom: A meta-analytical examination of the differences between demographic and job-related diversity relationships with performance. Organizational Behavior and Human Decision Processes; 119 (1): 38-53.

Vinnicombe S, Sealy R and Doldor E (2016) The Female FTSE Board Report 2016 Cranfield University. https://www.cranfield.ac.uk/press/news-2016/women-onboards-ftse-100-company-has-full-gender-balance-for-first-time.

Von Rönne R (8 April 2015) Warum mich der Feminismus anekelt. Die Welt. http://www.welt.de/kultur/article139269797/Warum-mich-der-Feminismus-ane kelt.html.

Wajcman J (1998) Managing Like a Man. Blackwell Publishers: Oxford.

Walter N (2015) Living Dolls: The Return of Sexism. Virago: London.

Wehrle M (2014) "Herr Müller, Sie sind doch nicht schwanger?!" Warum das Berufsleben einer Frau für jeden Mann ein Skandal wäre. Wilhelm Goldmann Verlag: München, Germany.

Weininger O (1997) Geschlecht und Charakter. Matthes \& Seitz Verlag: München, Germany.

WICT UK-International Women's day conference 2016. (8 March 2016) 117 Years-Are you prepared to wait that long for gender parity? http://wict-uk.co uk/event/wict-uk-international-womens-day-conference-2016/.

Williams Z (2013) Lean In: Women, Work, and the Will to Lead by Sheryl Sandberg-review. The Guardian. http://www.theguardian.com/books/2013/ $\mathrm{mar} / 13 /$ lean-in-sheryl-sandberg-review.

Wilson N and Altanlar A (2009) Director characteristics, gender balance and insolvency risk: an empirical study. SSRN Working Paper. http://ssrn.com/ abstract $=1414224$.

Wittenberg-Cox A (2012) Three Diversity "Best Practices" That Hurt Women. Harvard Business Review. https://hbr.org/2012/11/three-diversity-best-practices.

Wizorek A (2014) Weil ein \#Aufschrei nicht reicht. Für einen Feminismus von heute. Fischer: Frankfurt, Germany.

Wippermann C (2010) Frauen in Führungspositionen. Barrieren und Brücken. Bundesministerium für Familie, Senioren, Frauen und Jugend. http://www. bmfsfj.de/RedaktionBMFSFJ/Broschuerenstelle/Pdf-Anlagen/frauen-in-f_C3_ BChrungspositionen-deutsch, property $=$ pdf,bereich $=$ bmfsfi, sprache $=\mathrm{de}$, $\mathrm{rwb}=$ true.pdf.

Woetzel J et al (2015) How advancing women's equality can add \$12 trillion to global growth. McKinsey Global Institute Report. http://www.mckinsey.com/ global-themes/employment-and-growth/how-advancing-womens-equality-canadd-12-trillion-to-global-growth.

Wolf A (2013) The XX Factor. How Working Women are Creating a New Society. Profile Books: London. 
Wolf N (1991) The Beauty Myth: How Images of Beauty are Used Against Women. Vintage: London.

Women's Business Council. (2013) Executive Summary. http://womensbusiness council.dcms.gov.uk/executive-summary/.

World Economic Forum. (2015) The Global Gender Gap Report. http://www3. weforum.org/docs/GGGR2015/cover.pdf.

YouGov. (2016) 85\% of younger women in UK have been sexually harassed in public. http://www.endviolenceagainstwomen.org.uk/news/234/85-of-youngerwomen-in-uk-have-been-sexually-harassed-in-public.

\section{Data availability}

Data sharing is not applicable to this article as no datasets were generated or analysed during the current study.

\section{Additional information}

Competing interests: The author declares no competing financial interests.
Reprints and permission information is available at http://www.palgrave-journals.com/ pal/authors/rights_and_permissions.html

How to cite this article: Baumann H (2017) Stories of women at the top: narratives and counternarratives of women's (non-)representation in executive leadership. Palgrave Communications. 3:17009 doi: 10.1057/palcomms.2017.9.

(c) $\$$ This work is licensed under a Creative Commons Attribution-

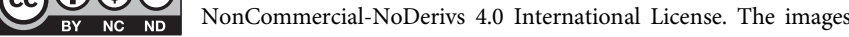
or other third party material in this article are included in the article's Creative Commons license, unless indicated otherwise in the credit line; if the material is not included under the Creative Commons license, users will need to obtain permission from the license holder to reproduce the material. To view a copy of this license, visit http:// creativecommons.org/licenses/by-nc-nd/4.0/ 